\title{
Scenarios of Business Development in the Agricultural Machinery Market Under Conditions of International Trade Integration
}

\author{
Tatiana N. Litvinova' ${ }^{1}$, Galina A. Khmeleva ${ }^{2,3}$, Lilia V. Ermolina ${ }^{4}$, Tatiana V. Alferova ${ }^{5}$, Irina V. Cheryomushkina ${ }^{6}$
}

\begin{abstract}
The purpose of the article is to identify and analyze scenarios of business development in the agricultural machinery market under conditions of international trade integration using the case of present-day Russia and to determine the need for state support for domestic production. As a methodological provision, we use the scenario analysis method adapted by the authors for the determination and analysis of possible scenarios of business development in the agricultural machinery market under conditions of international trade integration. From the research results, the authors conclude that the Russian agricultural machinery market develops dynamically under the influence of multiple favorable factors and positive tendencies, which include a population's income growth, increases in crop areas of farm crops, and state agricultural machinery modernization programs, among other. In view of recent events in the currency market, Russian manufacturers of agricultural machinery are presented with better opportunities to export their products. The performed analysis of features of the Russian agricultural machinery market under conditions of international trade integration shows that increased demand and market prices are probable and that this could lead to enterprise income growth. From our scenario analysis of business development in the agricultural machinery market under conditions of international trade integration, we identify the absence of an urgent need for state interference in market processes in the Russian market for agricultural machinery in the next five years.
\end{abstract}

KEY WORDS: $\quad$ business development, agricultural machinery market, international trade integration, scenario analysis

JEL Classification: Q170

${ }^{1}$ Volgograd State Agricultural University, Russia, ${ }^{2}$ Samara State University of Economics, Russia,

${ }^{3}$ Samara National Research University, Russia, ${ }^{4}$ Samara State Technical University, Russia,

${ }^{5}$ Perm State National Research University, Russia, ${ }^{6}$ Federal State Budget Educational Institution of Higher Education

"Voronezh State University of Engineering Technologies", Russia

\section{Introduction}

Through international trade integration, markets grow and entrepreneurs travel beyond national limits. Under such conditions, the level and nature of competi-

-

Correspondence concerning this article should be addressed to: Tatiana N. Litvinova, Volgograd State Agricultural University, Department of Management, Senior Lecturer, 11 Consular St., Volgograd, Russia, 400081, Tel.: +79880040771, E-mail: litvinova1358@yandex.ru tion in national markets changes, resulting in intensive fluctuations in market prices and changing demand volumes and preferences.

The agricultural machinery market is no exception - as integration processes in the global economy change, foreign suppliers appear in agricultural machinery markets, increasing competition and promoting the division of influence spheres and market structure changes. 
As a result, consumers can choose from a large variety of products and manufacturers of agricultural machinery can start to compete with one another for sales even more, leading to a reduction in general market prices and in buyer power growth.

Countries focused not only on meeting national demand but also on the preservation of national production face serious problems related to the reduction of competitiveness between domestic manufacturers, which cannot compete with global companies that have accumulated substantial financial and human resources and that employ superior technologies and equipment.

An inevitable result of a country's integration into the global economy pertains to the dilemma between consumer and manufacturer interests. Countries that prioritize consumers' interests risk becoming less productive and face problems related to economic security.

Countries that prioritize manufacturers' interests must interfere with market processes and expend public welfare in supporting domestic manufacturers. There is a risk of creating conditions that are too favorable for domestic manufacturers under which there are no incentives for development, spurring manufacturers' incapacities to adapt to new economic conditions and to compete in global markets.

This is why in developing state policies that support domestic manufacturers, it is necessary to develop a clear understanding of perspectives on business development in the agricultural machinery market under conditions of international trade integration without violating market mechanisms through state regulation.

This allows one to first identify the need for such interference and to second identify the most central avenues of regulation needed to achieve maximum effects with minimal expenditures. Consequently, the examination of perspectives of business development in the agricultural machinery market under conditions of international trade integration is feasible.

The purpose of the article is to identify and analyze scenarios of business development in the agricultural machinery market under conditions of international trade integration using the example of present-day Russia and to outline the need for state support for domestic production.

\section{Literature review}

Economic mechanisms, preconditions, and methodological aspects of business development in the agricultural machinery market under modern economic conditions have been studied in multiple works, including (Bortolini, Cascini, Gamberi, Mora, \& Regattieri, 2014a; Huang, Yun, You, \& Wu, 2011; Liu Hu, Jetté-Nantel, \& Tian, 2014; Staus \& Becker, 2012; Yakymenko, 2013; Yu, Leng, \& Zhang, 2012; Zhovnovach, 2014). In the agricultural machinery market, machinery and agricultural equipment is bought and sold (Muzlera, 2014). The following main segments of the agricultural machinery market can be identified: agricultural goods, combine harvesters, cultivators, walking tractors, plows, drill machines, and mowing machines, among others. (Bortolini, Mora, Cascini, \& Gamberi, 2014b). The agricultural machinery market is central for national food security, as it creates infrastructure needed for agriculture development (Morozova, Litvinova, Rodina, \& Prosvirkin, 2015).

Integration processes in the current global economy based on various forecasts and possible future change scenarios have been presented in the following works: (Anderson \& Valenzuela, 2011; Dasgupta, Pitigala, \& Gourdon, 2012; Golub \& Hertel, 2008; Palamarchyk, 2013; (Qobo, 2012, Sung, Delgado, Peña, \& Paladino, 2013). Integration involves closing of national economic systems (Bryant \& Javalgi, 2014) while preserving their capabilities for self-regulation and self-development (Kobrin, 2015). Within integration processes of the global economy, international standards and norms of economic activities appear in addition to international organizations that control their observation (Wirtz, Tuzovic, \& Ehret).

Peculiarities of business activities under conditions of international trade integration and global competition for enterprises operating in various countries and economic spheres have been examined in (Antonakakis \& Tondl, 2014; Ganushchak-Yefimenko, 2013a; Ganushchak-Yefimenko, 2013b; Gong \& Kim, 2013). Under conditions of international trading integration, entrepreneurs are presented with opportunities to enter new foreign markets (Bull, 2014). At the same time, foreign rivals appear in national markets (Wirtz et al., 2015). On the whole, strengthening competition is an integral component of integration processes in the global economic system (GonÇalves \& Madi, 2013). 
Table 1. Tree of scenarios

\begin{tabular}{ccc}
\hline Situation & Scenario $(\mathbf{S})$ & Probability of scenario $(\mathbf{P})$ \\
\hline Market price fluctuations & $S_{1 \text { price }}$ & $P_{1 \text { price }}$ \\
& $S_{2 \text { price }}$ & $P_{2 \text { price }}$ \\
Changes in demand volumes and & $\ldots$ & $\ldots$ \\
product sales & $S_{\text {nprice }}$ & $P_{\text {n price }}$ \\
& $S_{1 \text { demand }}$ & $P_{1 \text { demand }}$ \\
& $S_{2 \text { demand }}$ & $P_{2 \text { demand }}$ \\
& $S_{\text {ndemand }}$ & $\ldots$ \\
\hline
\end{tabular}

Table 2. Final scenario analysis table

\begin{tabular}{|c|c|c|c|c|c|}
\hline $\begin{array}{c}\text { Scenarios } \\
\text { of market } \\
\text { development }\end{array}$ & $\begin{array}{l}\text { Changes in prices } \\
\text { and demand }\end{array}$ & Probability & Price, RUB (P) & $\begin{array}{c}\text { Volume of sales, } \\
\text { items (V) }\end{array}$ & $\begin{array}{l}\text { Financial results, } \\
\text { RUB million (FR) }\end{array}$ \\
\hline \multirow[b]{2}{*}{$\begin{array}{l}\text { Most probable } \\
\text { scenario }\end{array}$} & $\mathrm{S}_{\text {price }}$ & $P_{\text {price }}(\max )$ & \multirow[b]{2}{*}{$P_{1}$} & \multirow[b]{2}{*}{$V_{1}$} & \\
\hline & $\mathrm{S}_{\text {demand }}$ & $P_{\text {demand }}(\max )$ & & & $\begin{array}{c}P_{\text {price }}(\max )^{*} \\
V^{1 *} \\
P_{\text {demand }}(\max )\end{array}$ \\
\hline$\ldots$ & $\ldots$ & $\ldots$ & $\ldots$ & $\ldots$ & $\ldots$ \\
\hline \multirow[b]{2}{*}{ Least likely scenario } & $\mathrm{S}_{\text {price }}$ & $P_{\text {price }}(\min )$ & $P_{5}$ & \multirow[t]{2}{*}{$V_{5}$} & $\begin{array}{l}\mathrm{P}_{5}^{*} \\
\mathrm{P}^{*} \text { (min }\end{array}$ \\
\hline & $\mathrm{S}_{\text {demand }}$ & $P_{\text {demand }}(\min )$ & & & $\mathrm{P}_{\text {demand }}(\mathrm{min})$ \\
\hline
\end{tabular}

Problems related to agricultural machinery market functioning under conditions of international trade integration and national agricultural machinery market state regulation for support purposes are outlined in the following works: (Clapp \& Helleiner, 2012; Khafizova, Galimardanova, \& Salmina, 2014; Mulatu \& Wossink, 2014; Vošta, 2014; Yushkevych, 2013). Under conditions of international trade integration, national markets of agricultural machinery face intensifying competitive struggles (Solovchuk, (2015) that foreign enterprises often win, compromising national food security (Gnedenko \& Kazmin, 2015). To protect national manufacturers, states regulate the development of agricultural machinery markets by providing tax subsidies and more favorable conditions for the economic activities of national manufacturers (Morozova \& Litvinova, 2014).

Our analysis of existing scientific works in this research area shows that these works examine specific aspects of the specified problem, leaving the necessity to conduct complex research on business development scenarios in agricultural machinery markets under conditions of international trade integration to address existing gaps and to formulate a comprehensive and objective understanding of future business activities in agricultural machinery markets.

\section{Method}

As a methodological provision, the scenario analysis approach adapted by the authors is applied to iden- 


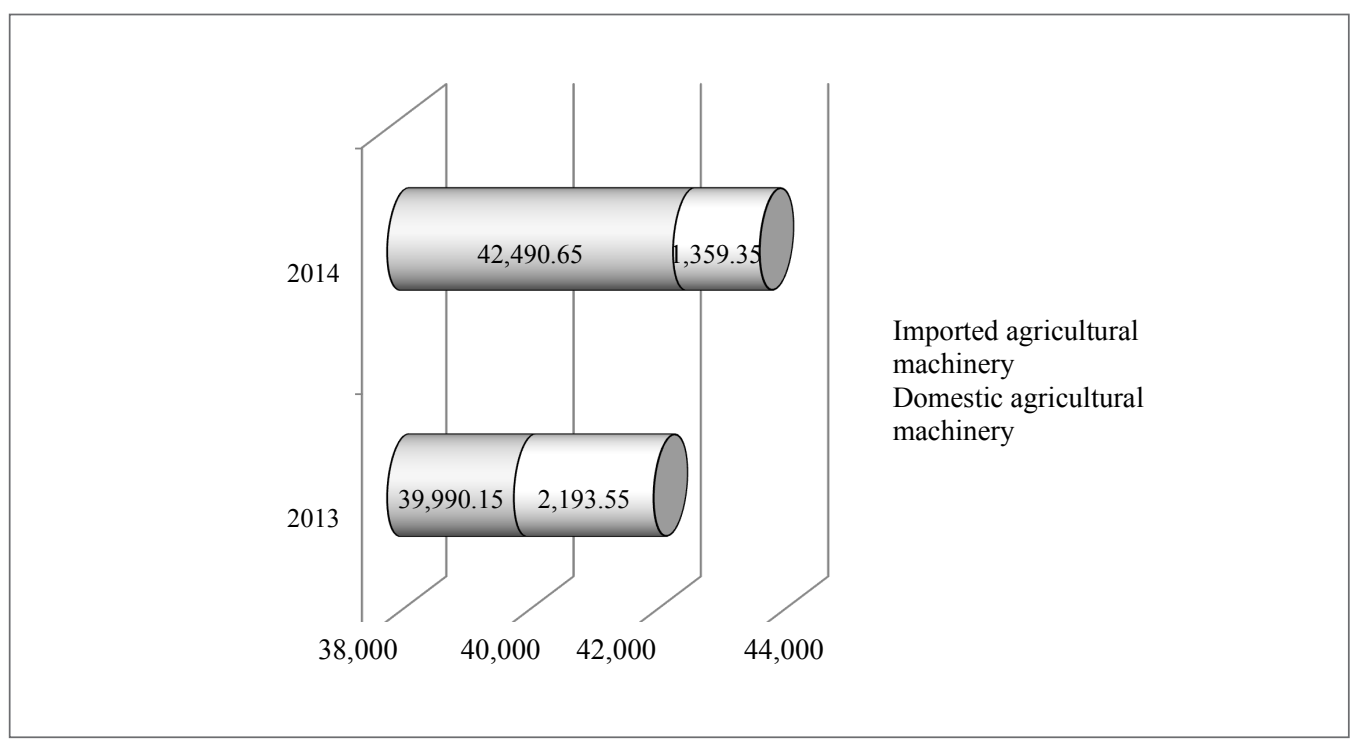

Figure 1. Dynamics and structure of the Russian agricultural machinery market in 2013-2014 Source: Adapted from "Manufacture of agricultural machinery in Russia in January-March 2015" by Agroinfo. Retrieved from http://agroinfo.com/proizvodstvo-selxoztexniki-v-rossii-v-yanvare-marte-2015-goda-1507201504

tify and analyze possible development scenarios of business in the agricultural machinery market under conditions of international trade integration. This approach is designed to identify factors that influence the agricultural machinery market.

On the basis of the determined factors, possible market price and sales volume changes and potential scenarios for such conditions are determined. Each scenario is assigned a possible probability value through expert evaluation through an analysis of market tendencies and factors of market development. As a result, a tree of scenarios was created (Table 1).

From probability scenarios of prices and demand changes, scenarios for the market as a whole and for businesses in this market were formed. The most likely scenario involves price and demand development with maximum probability. Then, scenarios of market development involving price reductions and demand change probability were formulated.

For each business development scenario, average market prices and total volumes of sales in the market were determined. From these data, balanced financial results (profits) were calculated as a product of the price and probability of changes under this scenario and of the volume of sales and probability of such a change under this scenario (Table 2).

The results of the scenario analysis identify future tendencies of business development in the market on the basis of an analysis of factors that influence this market. This methodology allows for the economic modeling and forecasting of market changes through mathematical instruments, ensuring the generation of precise and reliable results.

\section{Results}

Before presenting the results of the scenario analysis, let us outline the most important factors of business development in the agricultural machinery market under conditions of international trade integration. The most important of these is foreign competition.

According to data drawn from analytical and consulting company ACM-Holding, in 2014, the agricultural machinery market of Russia reduced by $3.8 \%$ relative to 2013. The total volume of agricultural machinery sales for January-December of 2014 amounted to 43,850 , with only 1,316 involving Russian machines (market share-3.1\%). 


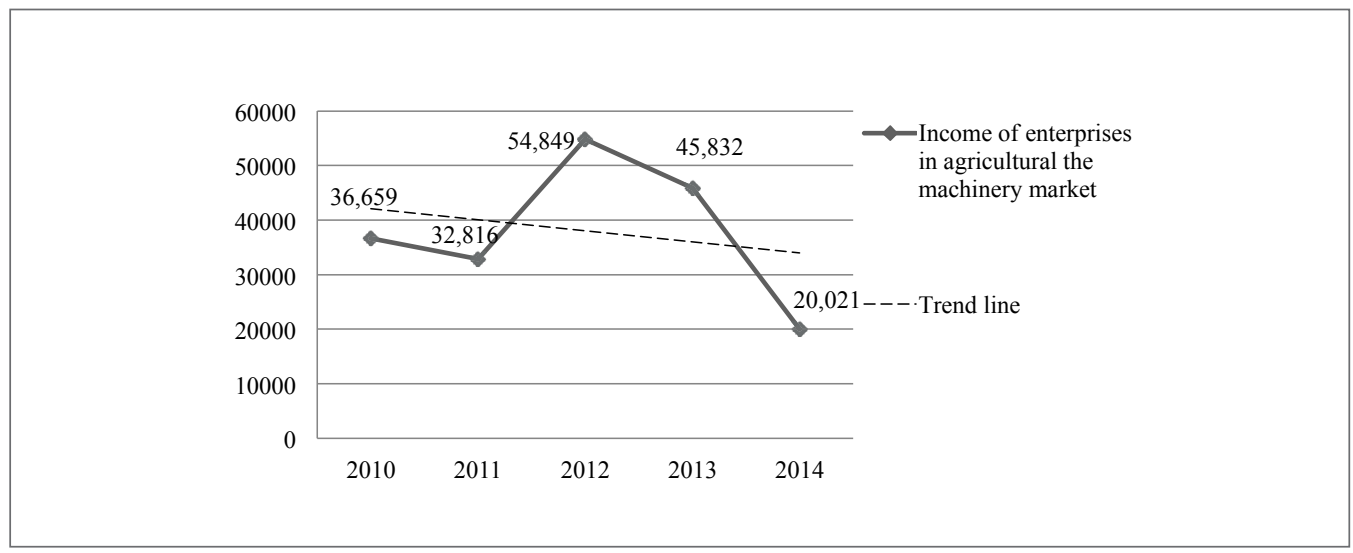

Figure 2. Enterprise profits in the agricultural machinery market from 2010-2014 in RUB million Adapted from "Russia in numbers. Scientific research and innovations 2015: Bulletin of Rosstat" by Rosstat (2015). Retrieved from http://www.gks.ru/free_doc/doc_2015/rusfig/rus-15.pdf

In 2014, the agricultural machinery market underwent an increase in the market share of imports of new foreign-branded agricultural machinery, which grew from $26.1 \%$ to $39.0 \%$, and import shares of used agricultural machinery grew from $7.1 \%$ to $8.2 \%$ in natural form; imports of used agricultural machinery grew by $10.7 \%$, to 3,590 items.

Overall, sales of imported agricultural machinery (used and new) grew by $36.6 \%$, increasing from 15,200 to 20,700 items (Agroinfo, 2015). The dynamics and structure of the Russian agricultural machinery market from 2013-2014 are shown graphically in Fig. 1.

Fig. 1 shows that the share of imported products in the Russian agricultural machinery market increased in 2014, posing potential losses in domestic production.

Another important feature of the development of the Russian market for agricultural machinery pertains to the growth in population income. As agricultural products and agricultural machinery are complementary goods, increased consumer demand for agricultural products increases demand for agricultural machinery from agricultural manufacturers.

Due to tendencies toward eco-product popularization, agricultural enterprises re-orient their activities toward such forms of production. To do so, new equipment from agricultural machinery manufacturers must be purchased.
Another factor that has affected the development of the Russian agricultural machinery market is Russia's Doctrine of Food Security to 2020, which calls for an increase in farm crop areas. This has also increased demand for agricultural machinery (Larionova, Suslova, Povorina, \& Vinogradova, 2015).

These factors also include Russian state programs for the modernization of agricultural machinery on the basis of national strategies of economic modernization. This has increased demand for agricultural machinery. From such increased demand under market forces, agricultural machinery prices will increase.

Recent trends in financial markets have led to the depreciation of the Russian ruble and have made the export of Russian agricultural machinery more profitable. In turn, Russian agricultural machines present price advantages, and despite their lower quality and weaker branding relative to foreign rivals, they are of interest to foreign customers, allowing Russian agricultural machinery manufacturers to compete successfully in foreign markets (Vinogradova, Kulyamina, Koroleva, \& Larionova, 2015).

A focus on exports will likely ensure the preservation of Russian agricultural machinery production even with a loss of positioning in the domestic market. However, when planning state strategies for the support of national production, it is not expedient to rely on the moods of players in financial markets alone, 
Table 3. Tree of changes in prices and demand in the Russian agricultural machinery market under conditions of international trade integration

\begin{tabular}{|c|c|c|c|}
\hline Situation & \multicolumn{2}{|c|}{ Scenario } & Probability of scenario \\
\hline \multirow{5}{*}{ Fluctuations in market prices } & \multirow{2}{*}{ Increase in prices } & by $5 \%$ & 0.3 \\
\hline & & by $10 \%$ & 0.5 \\
\hline & \multicolumn{2}{|c|}{ Prices are unchanged } & 0.1 \\
\hline & \multirow{2}{*}{ Reduction of prices } & by $3 \%$ & 0.06 \\
\hline & & by $5 \%$ & 0.04 \\
\hline \multirow{5}{*}{$\begin{array}{l}\text { Changes in the volume of } \\
\text { demand and in product sales }\end{array}$} & \multirow{2}{*}{ Increase in demand } & by $5 \%$ & 0.4 \\
\hline & & by $10 \%$ & 0.3 \\
\hline & \multicolumn{2}{|c|}{ Demand is unchanged } & 0.2 \\
\hline & \multirow{2}{*}{ Reduction of demand } & by $3 \%$ & 0.07 \\
\hline & & by $5 \%$ & 0.03 \\
\hline
\end{tabular}

Table 4. Final table for the scenario analysis of business development in the agricultural machinery market under conditions of international trade integration

\begin{tabular}{|c|c|c|c|c|c|c|}
\hline Scenario & Changes in pri & nd demand & Probability & Price, RUB & $\begin{array}{l}\text { Volume of } \\
\text { sales, items }\end{array}$ & $\begin{array}{c}\text { Financial } \\
\text { results, RUB } \\
\text { million }\end{array}$ \\
\hline \multirow{3}{*}{$\begin{array}{l}\text { Most likely } \\
\text { scenario }\end{array}$} & $\begin{array}{c}\text { Increase of } \\
\text { prices }\end{array}$ & by $10 \%$ & 0.5 & \multirow{3}{*}{$502,237.17$} & \multirow{3}{*}{46,042} & \multirow{3}{*}{$4,624.85$} \\
\hline & Increase in & & & & & \\
\hline & $\begin{array}{c}\text { Increase In } \\
\text { prices }\end{array}$ & by $5 \%$ & 0.4 & & & \\
\hline \multirow{3}{*}{$\begin{array}{l}\text { Highly probable } \\
\text { scenario }\end{array}$} & $\begin{array}{l}\text { Increase in } \\
\text { prices }\end{array}$ & by $5 \%$ & 0.3 & \multirow{3}{*}{$479,408.21$} & \multirow{3}{*}{48,235} & \multirow{3}{*}{$2,081.18$} \\
\hline & & & & & & \\
\hline & $\begin{array}{c}\text { prices } \\
\text { price in }\end{array}$ & by $10 \%$ & 0.3 & & & \\
\hline \multirow{3}{*}{$\begin{array}{l}\text { Scenario with } \\
\text { moderate } \\
\text { probability }\end{array}$} & \multirow{2}{*}{\multicolumn{2}{|c|}{ Prices are unchanged }} & 0.1 & \multirow{3}{*}{$456,579.25$} & \multirow{3}{*}{43,850} & \multirow{3}{*}{400.42} \\
\hline & & & & & & \\
\hline & Demand is & hanged & 0.2 & & & \\
\hline \multirow{2}{*}{ Unlikely scenario } & $\begin{array}{c}\text { Reduction of } \\
\text { prices }\end{array}$ & by $3 \%$ & 0.06 & \multirow[b]{2}{*}{$442,881.87$} & \multirow[b]{2}{*}{42,534} & \multirow[t]{2}{*}{79.12} \\
\hline & $\begin{array}{l}\text { Reduction of } \\
\text { demand }\end{array}$ & by $3 \%$ & 0.07 & & & \\
\hline \multirow{2}{*}{$\begin{array}{l}\text { Least likely } \\
\text { scenario }\end{array}$} & $\begin{array}{c}\text { Reduction of } \\
\text { prices }\end{array}$ & by $5 \%$ & 0.04 & \multirow[b]{2}{*}{$433,750.29$} & \multirow[b]{2}{*}{41,657} & \multirow[t]{2}{*}{21.68} \\
\hline & $\begin{array}{c}\text { Reduction of } \\
\text { demand }\end{array}$ & by $5 \%$ & 0.03 & & & \\
\hline
\end{tabular}



reduced price levels, sales volumes and profits, state regulation of the Russian agricultural machinery market will be necessary.

The results of the present study are limited by a number of factors affecting our forecasts of Russian agricultural machinery market development under conditions of international trade integration. Despite our thorough analysis of possible influencing factors, such factors are difficult to interpret and require further study; the precise treatment of their effects is also difficult to achieve. Therefore, our results should closely, but not fully, reflect real processes.

Further research in this area may involve monitoring the Russian agricultural machinery market to 2020 to identify realized scenarios, to verify the precision of formulated forecasts, and to identify additional factors shaping this market under conditions of international trade integration for the purposes of formulating new forecasts and increasing their precision.

\section{References}

Agroinfo. (2015, June 15). Manufacture of agricultural machinery in Russia in January-March 2015. (2015). Retrieved from http://agroinfo.com/proizvodstvo-selxoztexniki-v-rossii-v-yanvare-marte2015-goda-1507201504/

Anderson, K., Valenzuela, E. (2011). Agricultural policy as a barrier to global economic integration. In M. N. Jovanović (Ed.), International Handbook on the Economics of Integration (Vol. 3, pp. 225-239). Cheltenham, UK: Edward Elgar Publishing.

Antonakakis, N., Tondl, G. (2014). Does integration and economic policy coordination promote business cycle synchronization in the EU? Empirica, 41(3), 541-575.

Bortolini, M., Cascini, A., Gamberi, M., Mora, C., Regattieri, A. (2014a). Sustainable design and life cycle assessment of an innovative multi-functional haymaking agricultural machinery. Journal of Cleaner Production, 82, 23-36.

Bortolini, M., Mora, C., Cascini, A., \& Gamberi, M. (2014b). Environmental assessment of an innovative agricultural machinery. International Journal of Operations and Quantitative Management, 20(3), 243-258.

Bryant, C. E., \& Javalgi, R. G. (2014). Global economic integration in developing countries: The role of corruption and human capital investment. Journal of Business Ethics, 136(3), 437-450.
Bull, B. (2014). The development of business associations in Central America: The role of international actors and economic integration. Journal of Public Affairs, 14(3-4), 331-345.

Clapp, J., \& Helleiner, E. (2012). Troubled futures? The global food crisis and the politics of agricultural derivatives regulation. Review of International Political Economy, 19(2), 181-207.

Dasgupta, D., Pitigala, N., \& Gourdon, J. (2012). South Asia's economic prospects from global rebalancing and integration. In P. Dee (Ed.), Economic Reform Processes in South Asia: Toward Policy Efficiency (pp. 23-42). Abington, UK: Routlege.

Ganushchak-Yefimenko, L. M. (2013a). Economic integration as a basis for small and medium enterprises business. Actual Problems of Economics, 141(3), 70-77.

Ganushchak-Yefimenko, L. M. (2013b). Management of innovation potential development of small and medium business based on economic integration. Actual Problems of Economics, 144(6), 72-79.

Gnedenko, E., Kazmin, M. (2015). Agricultural land and regulation in the transition economy of Russia. International Advances in Economic Research, 21(3), 347-348.

Golub, A., Hertel, T. W. (2008). Global economic integration and land-use change. Journal of Economic Integration, 23(3), 463-488.

GonÇalves, J. R. B., Madi, M. A. C. (2013). Global economic integration, business expansion and consumer credit in Brazil, 1994-2010. International Journal of Green Economics, 7(3), 213-225.

Gong, C., Kim, S. (2013). Economic integration and business cycle synchronization in Asia. Asian Economic Papers, 12(1), 76-99.

Huang, H., Yun, Z., You, L., \& Wu, J. (2011). Forecast of subsidy for purchasing agricultural machinery based on Life Cycle Theory in China. Paper Presented at International Conference on Management and Service Science, "MASS 2011", August, 12-14, 2011, Wuhan, China.

Khafizova, A.R., Galimardanova, Y. M., Salmina, S.V. (2014). Tax regulation of activity of agricultural commodity producers. Mediterranean Journal of Social Sciences, 5(24), 421-425.

Kobrin, S. J. (2015). Is a global nonmarket strategy possible? Economic integration in a multipolar world order. Journal of World Business, 50(2), 262-272. 
Larionova, A. A., Suslova, I. A., Povorina, E. V., Vinogradova, M. V. (2015). Formation of tourist image of the region. Mediterranean Journal of Social Sciences, 6(3), 261-266.

Liu, Y., Hu, W., Jetté-Nantel, S., Tian, Z. (2014). The influence of labor price change on agricultural machinery usage in Chinese agriculture. Canadian Journal of Agricultural Economics, 62(2), 219-243.

Morozova, I. A., Litvinova, T. N. (2014). Russian market of agricultural equipment: Challenges and opportunities. Asian Social Science, 10(23), 68-77.

Morozova, I. A., Litvinova, T. N., Rodina, E. A., Prosvirkin, N. Y. (2015). Marketing mix in the market of agricultural machinery: Problems and prospects. Mediterranean Journal of Social Sciences, 6(36), 19-26.

Mulatu, A., Wossink, A. (2014). Environmental regulation and location of industrialized agricultural production in Europe. Land Economics, 90(3), 509-537.

Muzlera, J. (2014). Capitalization strategies and labor in agricultural machinery contractors in Argentina. Research in Rural Sociology and Development, 20, 57-74.

Palamarchyk, D. M. (2013). Integration into global production and marketing networks as a factor of influence on national economic development. Actual Problems of Economics, 149 (11), 51-56.

Popkova, E. G., Yurev, V., Stepicheva, O., Denisov, N. (2015). Transformation and concentration of intellectual capital as a factor of economic growth in the modern economy. Regional and Sectoral Economic Studies, 15(1), 53-60.

Qobo, M. (2012). Chasing after shadows or strategic integration?: South Africa and global economic governance. South African Foreign Policy Review, 1, 257-273.

Rosstat. (2015). Russia in numbers. Scientific research and innovations 2015: Bulletin of Rosstat. Retrieved from http://www.gks.ru/free_doc/ doc_2015/rusfig/rus-15.pdf

Rugman, A. M., Oh, C. H. (2011). Multinational enterprises and regional economic integration: Rethinking key metrics in international business. In M. N. Jovanović (Ed.), International Handbook on the Economics of Integration (Vol. 3, pp. 7387). Cheltenham, UK: Edward Elgar Publishing.

Solovchuk, K. O. (2015). Regulation and support for innovations in the agricultural sector of the European Union. Actual Problems of Economics, 165(3), 62-68.
Staus, A., Becker, T. (2012). Attributes of overall satisfaction of agricultural machinery dealers using a three-factor model. Journal of Business and Industrial Marketing, 27(8), 635-643.

Sung, H. E., Delgado, S., Peña, D., Paladino, A. (2013). Tyrannizing strangers for profit: Wage theft, crossborder migrant workers, and the politics of exclusion in an era of global economic integration. In D. C. Brotherton, D. L. Stageman, S. P. Leyro (Eds.), Outside Justice: Immigration and the criminalizing. Impact of changing policy and practice (pp. 247-267). New York, NY: Springer.

Vinogradova, M. V., Kulyamina, O. S., Koroleva, D. A., Larionova, A. A. (2015). The impact of migration processes on the National Security System of Russia. Mediterranean Journal of Social Sciences, 6(3), 161-168.

Vošta, M. (2014). The food market in the CR and its regulation within the framework of the EU agricultural policy. Agricultural Economics (Zemédělská ekonomika), 60, 279-286.

Wirtz, J., Tuzovic, S., Ehret, M. (2015). Global business services: Increasing specialization and integration of the world economy as drivers of economic growth. Journal of Service Management, 26(4), 565-587.

Yakymenko, O. S. (2013). Peculiarities in strategic management of enterprise development in agricultural machinery sector. Actual Problems of Economics, 147(9), 138-144.

Yu, X., Leng, Z., Zhang, H. (2012). Optimal models for impact of agricultural machinery system on agricultural production in Heilongjiang agricultural reclamation area. Paper presented at Proceedings 24th Chinese Control and Decision Conference, “CCDC 2012”, May 23-25, 2012, Taiyuan, China.

Yushkevych, O. O. (2013). Regulation mechanisms in the development of agricultural enterprises. Actual Problems of Economics, 147(9), 132-137.

Zhovnovach, R. I. (2014). Satisfaction of consumers' demand as the basis for planning competitiveness of agricultural machinery enterprises. Actual Problems of Economics, 155(5), 171-180. 
